\title{
Bay-scale spatial growth variation of mussels Mytilus edulis in suspended culture, Prince Edward Island, Canada
}

\author{
Linda Waite ${ }^{1,3, *}$, Jon Grant ${ }^{2}$, Jeffrey Davidson ${ }^{1}$ \\ ${ }^{1}$ Atlantic Veterinary College, Department of Health Management, Charlottetown, Prince Edward Island C1A 4P3, Canada \\ ${ }^{2}$ Dalhousie University, Department of Oceanography, Halifax, Nova Scotia B3H 4J1, Canada
}

${ }^{3}$ Present address: 202 Reade Street, Moncton, New Brunswick E1C 6S6, Canada

\begin{abstract}
Spatial growth variation of experimentally cultured blue mussels Mytilus edulis in Tracadie Bay, Prince Edward Island, Canada, was consistent in both years of a 2 yr study. The spatial pattern displayed reduced tissue growth along a gradient of decreasing tidal exchange from the inlet mouth to the inner estuary. There was no indication of persistent spatial differences in seston concentration among stations. The data imply that the flux of food (expressed as the product of concentration and current speed) controls the spatial variation in growth, with decreasing flux from the outer to inner bay. Growth trajectories analysed by polynomial regression differed between years despite spatial similarities within each year. Results of multiple regression analyses explaining mussel growth suggested that temporal variability in seston characteristics was more important in explaining growth than annual mean seston levels. Chlorophyll $a$ and meat weight showed similar patterns of increase during 1998. In 1999, higher summer temperatures were more important in determining upper limits of growth, with later growth stimulation apparently in response to an autumn phytoplankton bloom. The pattern of spatial variability in mussel growth, representing decreased growth rates in the inner relative to the outer bay, provided evidence that the density of mussels in Tracadie Bay was exceeding the food supply.
\end{abstract}

KEY WORDS: Mussels $\cdot$ Mussel growth $\cdot$ Food availability $\cdot$ Phytoplankton $\cdot$ Aquaculture $\cdot$ Carrying capacity

Resale or republication not permitted without written consent of the publisher

\section{INTRODUCTION}

Blue mussels Mytilus edulis have a high filtration capacity that may deplete the water column of particles (seston), potentially causing food limitation in culture settings (Grant 1996, Dolmer 2000). The amount of available food at local and embayment scales is dependent on stocking density, seston concentration and hydrodynamics (Dame \& Prins 1998). Bivalve density has an increasingly negative effect on growth in locations with higher water-residence times and/or shallower water depth (Bacher et al. 2003). As embayments are filled with culture, water turnover becomes limiting with regard to seston renewal and, hence, food limitation to growth. This limitation is most likely to occur in inner reaches of bays where sites are at the extremes of tidal exchange. Mussel farms on Prince Edward Island (PEI) occupy much of the space available for culture, and therefore a strong spatial growth gradient within these densely stocked embayments might be expected. The industry has grown rapidly since the 1980s to current production levels approximating $20000 \mathrm{mt}$ annually (for further information see: www.dfo-mpo.gc.ca). Estimates of the ability of these embayments to sustain production levels (i.e. carrying capacity) are required to optimise management decisions in conjunction with defining the suitability of sites for mussel culture. Space limitation in PEI via overstocking may be indicated by slower growth rates and lower yields (Scarratt 2000). 
There are many scales at which food limitation can affect the growth of cultured bivalves. High density at a local scale (e.g. within socking sleeves) may lead to reduced growth of interior bivalves (Parsons \& Dadswell 1992, Côté et al. 1994). Seston depletion resulting from the distribution of bivalves on longlines may also affect their growth in the centre of a farm (Pilditch et al. 2001). A large-scale gradient in mussel growth can occur as a result of the interaction between the distribution of phytoplankton, the filtration capacity of local populations, and water circulation patterns in heavily cultured embayments (Dolmer 2000). Seston depletion might be expected to be most severe in the innermost part of a bay if the majority of the food supply is from incoming tides (Dowd 2000). There are surprisingly few studies of spatial variation in growth of cultured bivalves despite the potential importance of this factor to shellfish growth.

This study investigated the relationship between blue mussel growth and food supply within an intensely cultured embayment in PEI. Mussel growth was measured coincident with monitoring seston concentrations and temperature at 5 geographically distinct locations within the embayment. Growth trajectories were described statistically and the interaction between mussel growth, environmental variables, and location examined. In addition, growth was monitored over $2 \mathrm{yr}$, allowing measurement of interannual as well as spatial variation.

\section{MATERIALS AND METHODS}

Study area. Tracadie Bay is a small, semi-enclosed embayment (total area $14 \mathrm{~km}^{2}$, mean depth $4 \mathrm{~m}$ ), opening to the Gulf of Saint Lawrence through a single narrow channel (Fig. 1); 2 deep-water channels with strong currents (up to $70 \mathrm{~cm} \mathrm{~s}^{-1}$ ) branch off from the main channel and are separated by intertidal flats. Tides are diurnal to semidiurnal with a range of $\sim 60 \mathrm{~cm}$ (Dowd et al. 2001, Grant et al. in press). Mussels are cultured throughout the main bay, and to a lesser extent in Winter Bay. The embayment is normally covered by ice from late December to late April. We established 5 sampling sites (Fig. 1) to portray the diverse biophysical conditions within the system and locations where mussel culture is practised.

Mussel growth. Seed stock used in growth experiments were obtained from a sample of approximately 5000 juvenile mussels of uniform size collected in May of 1998 and 1999 from a cultured stock in the inner area of Tracadie Bay. Undersized mussels were culled; 30 mussels were randomly selected from the sample for subsequent measurement of shell length and determination of dry meat weight. Subsamples of 500 mus-

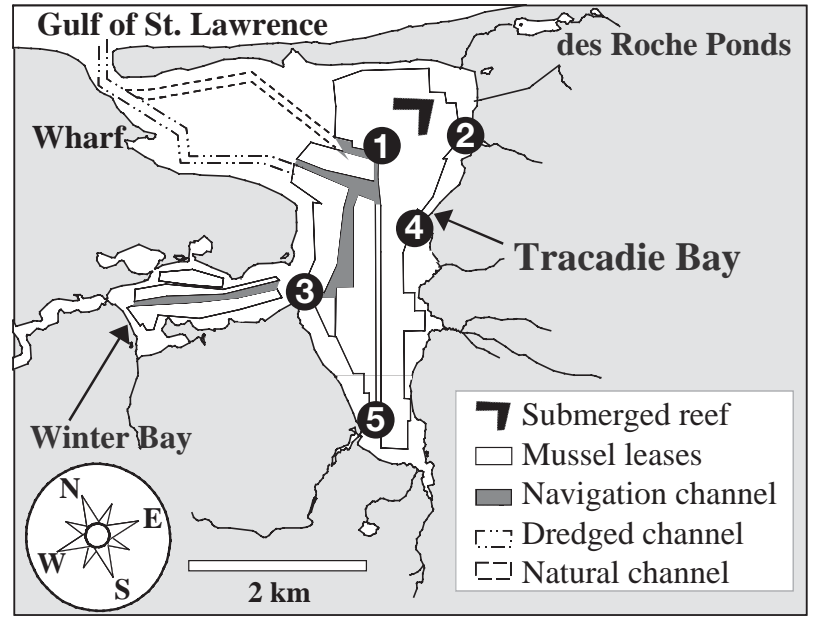

Fig. 1. Map of Tracadie Bay, Prince Edward Island, showing 5 sites used to assess mussel growth and environmental parameters from May to October 1998 and 1999

sels were selected at random and transferred to each of five $1.27 \mathrm{~cm}$-mesh Vexar bags $(85 \times 45 \times 10 \mathrm{~cm})$. Each bag was inserted into a rigid, plastic-wrapped wiremesh cage. The cages were then transported to the 5 sites within the embayment. Cages were tied to concrete blocks and buoyed to float at $2 \mathrm{~m}$ below the water surface. Cages and bags were cleaned of excess fouling and sediment with a stiff brush. The mussels were transferred to clean cages and bags during the summer. A sample of 30 mussels was collected at each of the 5 sites during 14 sampling trips in 1998 and 1999 (Table 1), and frozen until processed. The declining

Table 1. Mytilus edulis. Sampling schedule used to assess growth and environmental parameters at 5 sites in Tracadie Bay, Prince Edward Island, from May to October 1998 and 1999. Each site sample consisted of 30 mussels, 1 water sample at mussel-cage depth, and 1 CTD cast

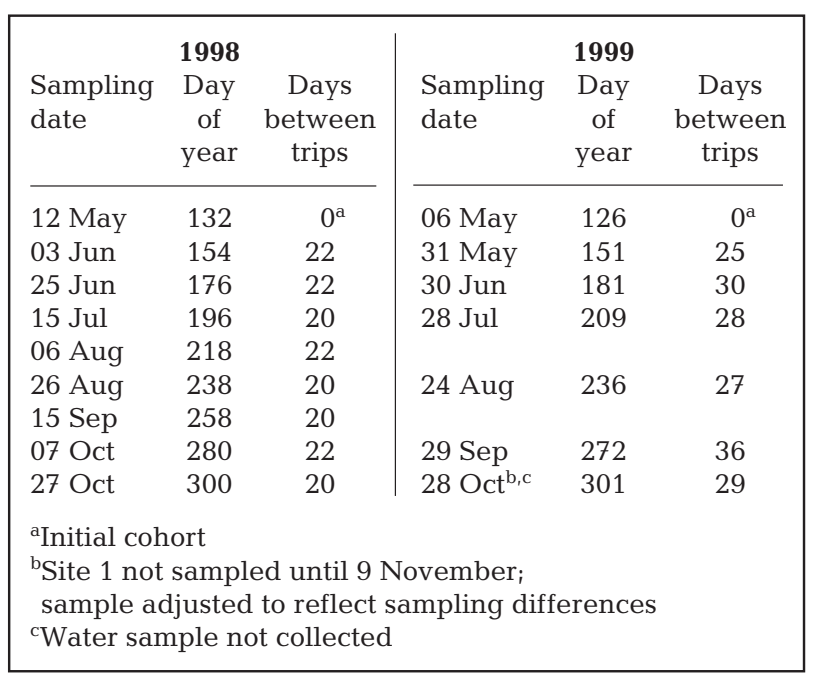


densities of mussels in the cages, due to successive sampling, were assumed to equally affect mussel growth at each site. Dry meat weight was determined after dissecting the meat from the shell and drying at $70^{\circ} \mathrm{C}$ for $24 \mathrm{~h}$. Shell length was determined by measuring the maximum anterior-posterior axis of the shell with an electronic calliper $( \pm 0.02 \mathrm{~mm})$.

Environmental sampling. Water samples for seston determinations were collected on 15 sampling dates coincident with mussel sampling (Table 1). At each site, a water sample was collected at cage depth using a Niskin bottle, transferred into an opaque container, kept shaded, and processed within $3 \mathrm{~h}$ of collection. Suspended particulate matter concentration (SPM, $\mathrm{mg} \mathrm{l}^{-1}$ ), was determined from single water samples of 1 to 21 each filtered onto washed, ashed and preweighed Whatman GF/C $47 \mathrm{~mm}$ filters, rinsed with deionized water, and frozen. Filters were dried at $70^{\circ} \mathrm{C}$ for $24 \mathrm{~h}$, weighed to determine SPM, then ashed at $450^{\circ} \mathrm{C}$ for $24 \mathrm{~h}$ and reweighed to determine particulate inorganic matter (PIM, mg $\mathrm{l}^{-1}$ ). Particulate organic matter (POM, mg $\mathrm{l}^{-1}$ ) was calculated by subtraction. The quality of the seston was expressed as percentage organic SPM (\% POM). Plant pigment concentrations (chlorophyll $a, \mu g \mathrm{l}^{-1}$ and phaeophytin $a, \mu g \mathrm{l}^{-1}$ ) were determined by filtering triplicate water samples of $100 \mathrm{ml}$ onto $0.25 \mathrm{~mm}$ Whatman GF/C filters and freezing at $-20^{\circ} \mathrm{C}$ in darkness. The pigments were extracted from the filter within 24 to $48 \mathrm{~h}$ of collection with $10 \mathrm{ml}$ of $90 \%$ acetone over $24 \mathrm{~h}$, and analyzed using a Turner Designs $^{\mathrm{TM}}$ fluorometer equipped with a chlorophyll $a$ accessory kit. Water temperature $\left({ }^{\circ} \mathrm{C}\right)$ at each sampling site was recorded continuously at $15 \mathrm{~min}$ intervals throughout the study using VEMCO ${ }^{\mathrm{TM}}$ minilog temperature probes attached to the door of each mussel cage. Spikes in temperature data, caused by routine lifting of the cages, were removed. Temperature was monitored at all sites from 12 May to 15 October in 1998 and from 6 May to 28 October in 1999. Daily water temperatures were calculated for descriptive purposes.

Data analyses. Temporal trends and location responses of mussel shell length and meat growth were examined using within-subject regression models (Brown 1988, Hopkins 2000 at www.sportsci.org/ resource/stats). Second-order polynomial regressions $\left(Y=A+B X+C X^{2}\right)$ for each site and for each year, derived from repeated measurements, were used because mussel growth trajectories displayed monotonic but non-linear relationships. Multicolinearity between regression coefficients was reduced by using an $(X-\bar{X})$ transformation (Neter et al. 1996). $A, B$ and $C$ regression coefficients were extracted for further analyses. Due to normalization with the mean, the $A$ coefficient (i.e. intercept of polynomial regressions) is the calculated value of shell length or meat weight at the mid- point of the sampling year. The $B$ coefficient (linear function) provides an average daily rate of change (i.e. $\mathrm{d}^{-1}$ ) in shell length or dry meat weight from the beginning to the end of the sampling period; i.e. a measure of net growth which integrates seasonal as well as initial differences in the size of individual mussels used as stock. The $C$ coefficient (quadratic function) describes the degree of change in growth rates from mid-summer. The mid-point of the sampling year occurred on 4 August in 1998 and 2 August in 1999. Each polynomial regression coefficient was divided by its standard error to obtain a $t$-statistic to evaluate its usefulness as a predictor (using SPSS regression analysis). Pair-wise comparisons of regression coefficients were then made between sites and years using an independent $t$-test $(t=$ $\left|C_{a}-C_{b}\right| / \sqrt{S E_{a}^{2}+S E_{b}^{2}}$ ) (Motulsky \& Christopoulos 2003) with Bonferroni corrections. Dry meat weight values at Site 1 on Year Day (YD) 300 and at Site 2 on YD 280 were removed because meat weight loss was probably associated with observed spawnings.

Identification of temporal trends and associations between environmental and mussel growth variables was made by construction of a Pearson correlation (r) matrix. Variable relationships were visually examined to assess linearity assumptions prior to analyses. Appropriate data transformations were employed when an assumption was violated. Percent (\%) POM was arcsine-transformed. Homoscedasticity was verified using Levene's test (Snedecor \& Cochran 1989) prior to conducting each analysis of variance.

In addition to growth variables derived from polynomial regression, the period of peak annual shell length and dry meat weight (October values) were compared between sites for each year using 1-way analysis of variance. Bonferroni-adjusted post-hoc multiple comparisons were employed to determine statistical differences. To compare values between years, mixedeffects nested analyses of variance (year within site) were performed on mussel shell length and dry meat weight in late October, and on seston parameters within a site. Linear contrast tests were employed for post-hoc comparisons.

Forward stepwise multiple regressions were used to assess the association between environmental variables and mussel size (meat weight). Potential predictor variables were water temperature, concentrations of chlorophyll $a$, POM and SPM, and \% POM values. $\mathrm{VEMCO}^{\mathrm{TM}}$ minilog temperature values were averaged between sampling dates at each of the 5 sites to produce a variable of comparable interval to seston. Water temperature readings in July 1998 at Site 1 were not included in analyses because of equipment malfunction. Departures from normality and homogeneity of variance were checked to assess the best fit of regression models to the data. 
Shell length
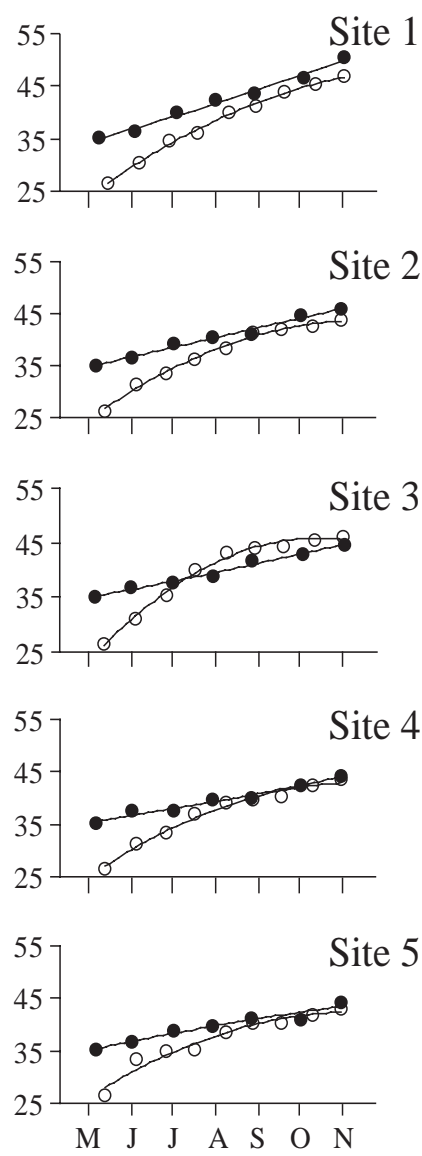

Dry meat weight
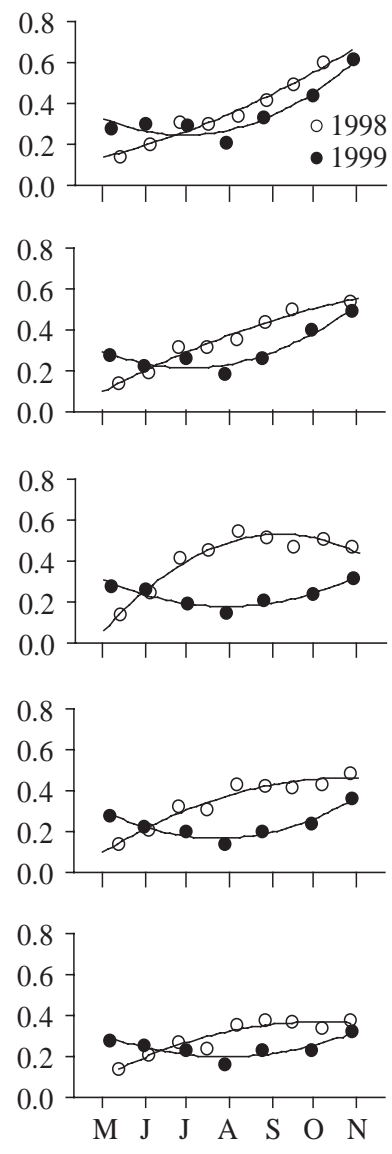

Month

Fig. 2. Mytilus edulis. Mussel shell length (mm) and meat weight $(\mathrm{g})$ growth curves at the 5 study sites from May to October 1998 and 1999. Each data point represents average of 30 mussels. Meat weight values for October removed in 1998 for Sites 1 and 2 because of spawning

\section{RESULTS}

\section{Mussel growth}

\section{Growth trajectories}

Regression provided a reliable method for describing shell length and meat weight trajectories for the experimentally grown mussels (Fig. 2, Table 2). Second-order polynomial functions were fitted to all data for comparative purposes. Shell length increase was curvilinear in 1998 and distinctly linear in 1999 (Fig. 2). The quadratic term ( $C$ coefficient) for shell length was significantly negative at all sites in 1998 reflecting the slowing of shell growth later in the year (Table 2). This term was not significant in the regressions fitted to shell length in 1999. Meat weight trajectories were also different between years (Fig. 2) but changes in dry meat weight were less consistent among sites in 1998. The $C$ coefficient was not significant at Sites 1 and 2 (i.e. constant growth), but was significantly negative at Sites 3, 4 and 5 where plateaus in meat weight were apparent in 1998 (Fig. 2, Table 2). In 1999, changes in dry meat weight at all sites were consistent with an initial decline in weight followed by increases after midsummer (Fig. 2). The linear function for meat growth in 1999 at Site 5 was non-significant but with the addition of a quadratic function, the regression was significant at $\mathrm{p}=0.10$, and the $\mathrm{R}^{2}$ significantly increased by $74 \%$ (Table 2). Therefore, a second-order polynomial was also fitted to this data for comparative purposes. The quadratic coefficient $C$ was significantly positive across sites (Table 2), reflecting the exponential upward trend during the latter half of the year.

There were differences in the relative importance of the sampling location within each year in addition to

Table 2. Mytilus edulis. Coefficients of regressions $\left(Y=A+B X+C X^{2}\right)$ fitted to average mussel shell length and meat weight data at 5 sites in Tracadie Bay from May through October 1998 (9 samples per site) and 1999 (6 samples per site). Goodness-of-fit $\left(\mathrm{R}^{2}\right)$ and significance $(\mathrm{p})$ of regression and regression coefficients $(A, B, C)$ are indicated. ${ }^{*} \mathrm{p}<0.05,{ }^{* *} \mathrm{p}<0.01,{ }^{* * *} \mathrm{p}<0.001$

\begin{tabular}{|c|c|c|c|c|c|c|c|c|c|c|c|c|}
\hline \multirow{2}{*}{$\begin{array}{l}\text { Coef- } \\
\text { ficient }\end{array}$} & \multicolumn{5}{|c|}{ Shell length (mm) at Site } & \multicolumn{7}{|c|}{ Dry meat weight (g) at Site } \\
\hline & 1 & 2 & 3 & 4 & 5 & & 1 & 2 & 3 & 4 & 5 & \\
\hline \multicolumn{13}{|l|}{1998} \\
\hline$A$ & $39.40^{* * *}$ & $38.73^{* * *}$ & $42.14^{* * *}$ & $38.37^{* * *}$ & $38.35^{* * *}$ & & $0.361^{* * *}$ & $0.383^{* * *}$ & $0.506^{* * *}$ & $0.387^{* * *}$ & $0.329^{* * *}$ & \\
\hline$B$ & $0.11^{* * *}$ & $0.09^{* * *}$ & $0.09^{* * *}$ & $0.08^{* * *}$ & $0.07^{* * *}$ & & $0.315^{* * *}$ & $0.230^{* * *}$ & $0.115^{* *}$ & $0.161^{* * *}$ & $0.108^{* *}$ & $\left(\times 10^{2}\right)$ \\
\hline$C$ & $-0.39^{* *}$ & $-0.49^{* * *}$ & $-0.87^{* * *}$ & $-0.48^{* *}$ & $-0.44^{*}$ & $\left(\times 10^{3}\right)$ & 0.067 & -0.058 & $-0.292^{* *}$ & $-0.119^{*}$ & $-0.109^{*}$ & $\left(\times 10^{4}\right)$ \\
\hline $\mathrm{R}^{2}$ & 0.996 & 0.993 & 0.992 & 0.985 & 0.952 & & 0.967 & 0.970 & 0.953 & 0.943 & 0.902 & \\
\hline $\mathrm{p}$ & $* * *$ & $* * *$ & $* * *$ & $* * *$ & ${ }^{* * *}$ & & $* * *$ & $* * *$ & $* * *$ & $* * *$ & ** & \\
\hline \multicolumn{13}{|l|}{1999} \\
\hline$A$ & $42.09^{* * *}$ & $40.55^{* * *}$ & $39.71^{* * *}$ & $39.46^{* * *}$ & $39.89^{* * *}$ & & $0.273^{* * *}$ & $0.233^{* * *}$ & $0.178^{* * *}$ & $0.169^{* * *}$ & $0.198^{* * *}$ & \\
\hline$B$ & $0.08^{* * *}$ & $0.06^{* * *}$ & $0.05^{* * *}$ & $0.05^{* * *}$ & $0.05^{* *}$ & & $0.164^{* *}$ & $0.125^{* *}$ & 0.012 & 0.037 & $0.011^{*}$ & $\left(\times 10^{2}\right)$ \\
\hline$C$ & 0.05 & 0.00 & 0.03 & 0.05 & -0.06 & $\left(\times 10^{3}\right)$ & $0.238^{*}$ & $0.208^{*}$ & $0.165^{* *}$ & $0.197^{* *}$ & $0.136^{*}$ & $\left(\times 10^{4}\right)$ \\
\hline $\mathrm{R}^{2}$ & 0.989 & 0.981 & 0.982 & 0.967 & 0.947 & & 0.924 & 0.924 & 0.883 & 0.934 & 0.762 & \\
\hline $\mathrm{p}$ & $* * *$ & $* * *$ & $* * *$ & $* *$ & $* *$ & & $* *$ & $* *$ & $*$ & $* *$ & 0.056 & \\
\hline
\end{tabular}




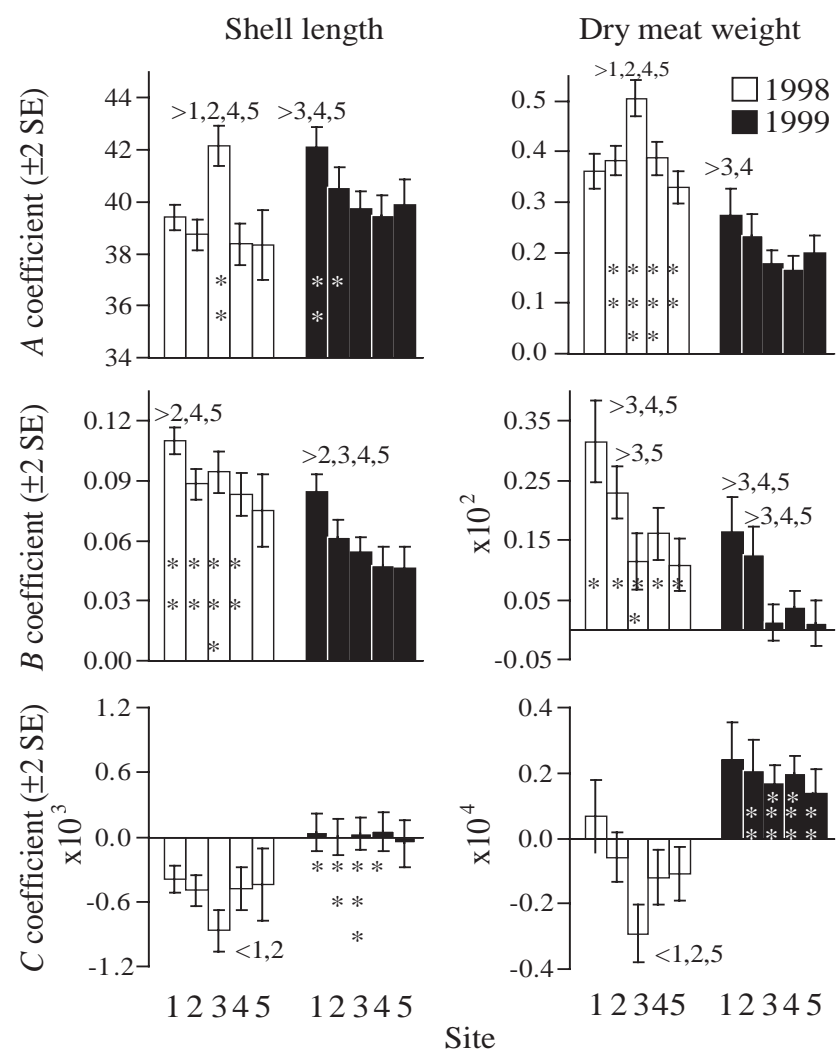

Fig. 3. Mytilus edulis. Comparisons of average $( \pm 2 \mathrm{SE})$ annual polynomial regression coefficients $(A, B, C)$ fitted to mussel shell length $(\mathrm{mm})$ and dry meat weight $(\mathrm{g})$ at the 5 study sites from May to October 1998 and 1999. Significant differences between sites within same year indicated above bars, and between years at similar sites on bars. $* p<0.05$, ** $p<0.01$, $* * * \mathrm{p}<0.001$

the difference in the shape of the growth trajectories between years (Table 2). In 1998, Site 3 dominated growth prior to mid-summer where the largest midsummer shell length and heaviest mid-summer, meat weight occurred while shell length and meat weight at the other 4 sites were comparable by mid-summer ( $A$ coefficient, Fig. 3). The fastest overall growth occurred in shell length and meat weight ( $B$ coefficient) at Site 1 from mid-summer into autumn 1998, and the greatest negative impact on growth occurred at Site 3 (significantly smaller $C$ coefficient, Fig. 3). The increase in meat weight was relatively more important than the shell length increase at Site 2 in 1998, while mussels at Sites 3, 4 and 5 showed poorer meat growth ( $B$ coefficients, Fig. 3). In 1999, shell length and meat weight were ranked from the outer to inner bay, with Site 1 dominating in size and growth rate (Fig. 3). The growth rate indicated by the $B$ coefficient in 1999 demonstrated a site-effect with overall growth in meat weight at Sites 1 and 2 far exceeding that at the 3 inner sites (Fig. 3). There was no significant difference detected
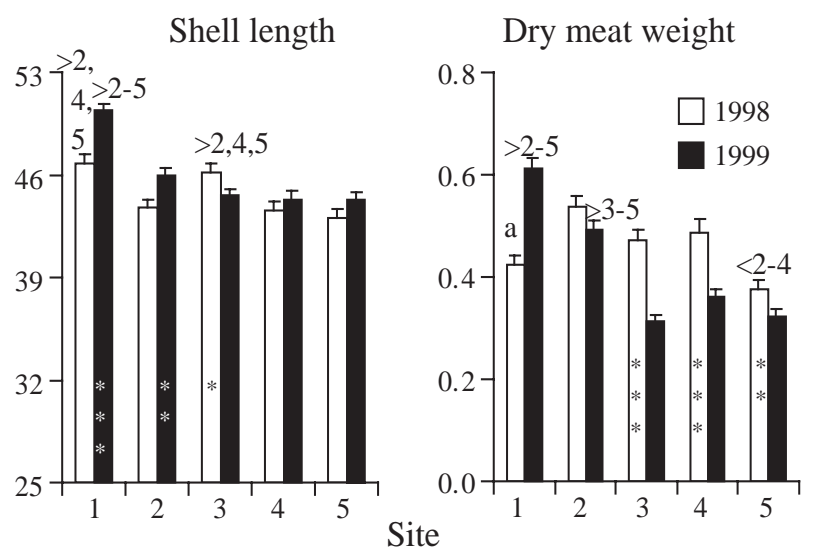

Fig. 4. Mytilus edulis. Average (+1 SD) shell length (mm) and dry meat weight $(\mathrm{g})$ at the 5 study sites during late October 1998 and 1999 in Tracadie Bay. Each bar represents an average of $\sim 30$ mussels. a: reduced weight due to spawning; further details as in Fig. 3

in the rate of increase ( $C$ coefficients) of meat weight among sites during the latter part of 1999.

\section{Annual variation}

Shell length and meat weight at the end of the growth experiments in October each year provided a 'final' measure of net growth that integrates seasonal dynamics as well as initial differences in the size of individuals used as stock. In both years, Site 1 achieved the greatest shell length, and final size was larger in 1999 than in 1998 (Fig. 4). Site 3 stood out as being greater in shell length than Sites 2, 4 and 5 in 1998 and having greater shell length in 1998 than in 1999. Inner Sites 4 and 5 displayed no difference in final shell length within or between years.

Dry meat weight in October 1998 had reduced intersite differences related to weight reduction due to spawning at Sites 1 and 2 (Fig. 4). The innermost Site 5 had the smallest final meat weight. Compared to 1998, dry meat weight in October 1999 was more distinct with respect to site (Fig. 4) with Sites 1 and 2 dominant as in the growth rate results from the regression analyses (Fig. 3). Interannual comparisons of October meat weight showed significantly greater growth in 1998 than in 1999 (Fig. 4), reflecting the generally poor growth performance seen at Inner Sites 3 to 5 in 1999.

In summary, annual and spatial differences were more pronounced for meat weight growth than for shell length growth (Fig. 3). Regression analyses of shell and meat growth trajectories indicated superior net growth performance at Site 1, followed by Site 2 . The most rapid shell and meat growth during the study occurred prior to mid-summer 1998 at intermediate 


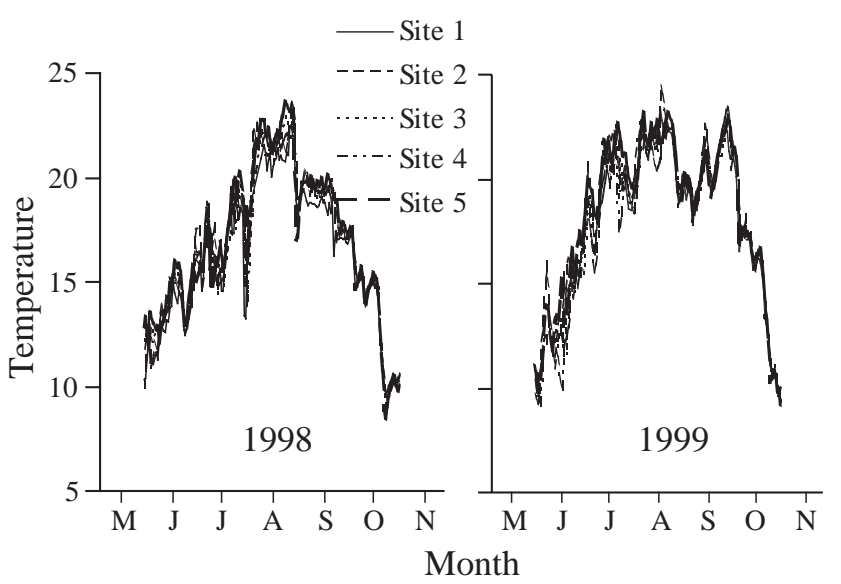

Fig. 5. Average daily water temperature $\left({ }^{\circ} \mathrm{C}\right)$ recorded at the 5 study sites from May to October 1998 and 1999

Site 3, but this growth was not sustained. Shell length and meat weight were similar throughout most of the embayment by mid-summer 1998, but differed between the inner and outer areas in mid-summer 1999 (A coefficient, Fig. 3).

\section{Environmental conditions}

Water temperature and salinity

Water temperatures in Tracadie Bay during 1998 and 1999 increased from $<10^{\circ} \mathrm{C}$ in May to summer maxima approaching $25^{\circ} \mathrm{C}$ in early August followed by a decrease to $<10^{\circ} \mathrm{C}$ in October (Fig. 5). Sustained daily water temperatures $>20^{\circ} \mathrm{C}$, a level potentially limiting to mussel growth, were less frequent in 1998 (32 d during mid-July through early August) than in 1999 (74 d during late June through mid-September). Tempera-

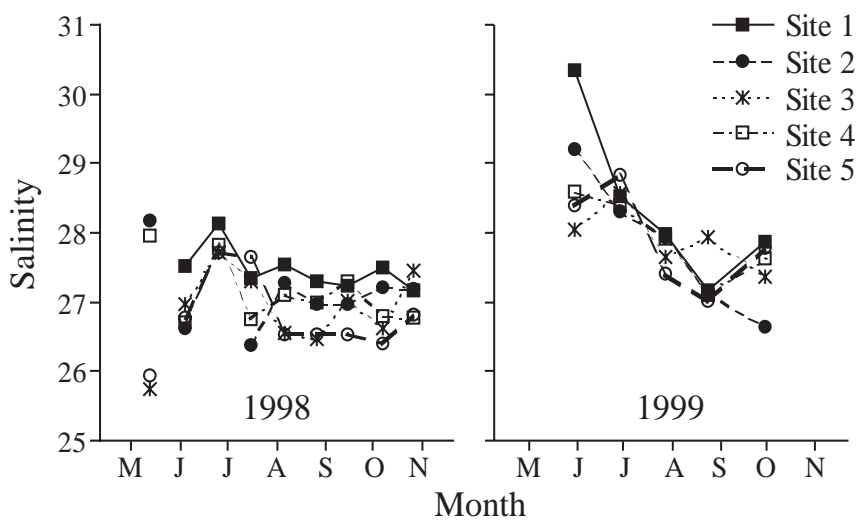

Fig. 6. Derived salinity values (from CTD casts) recorded at the 5 study sites from May to October 1998 and from May to September 1999
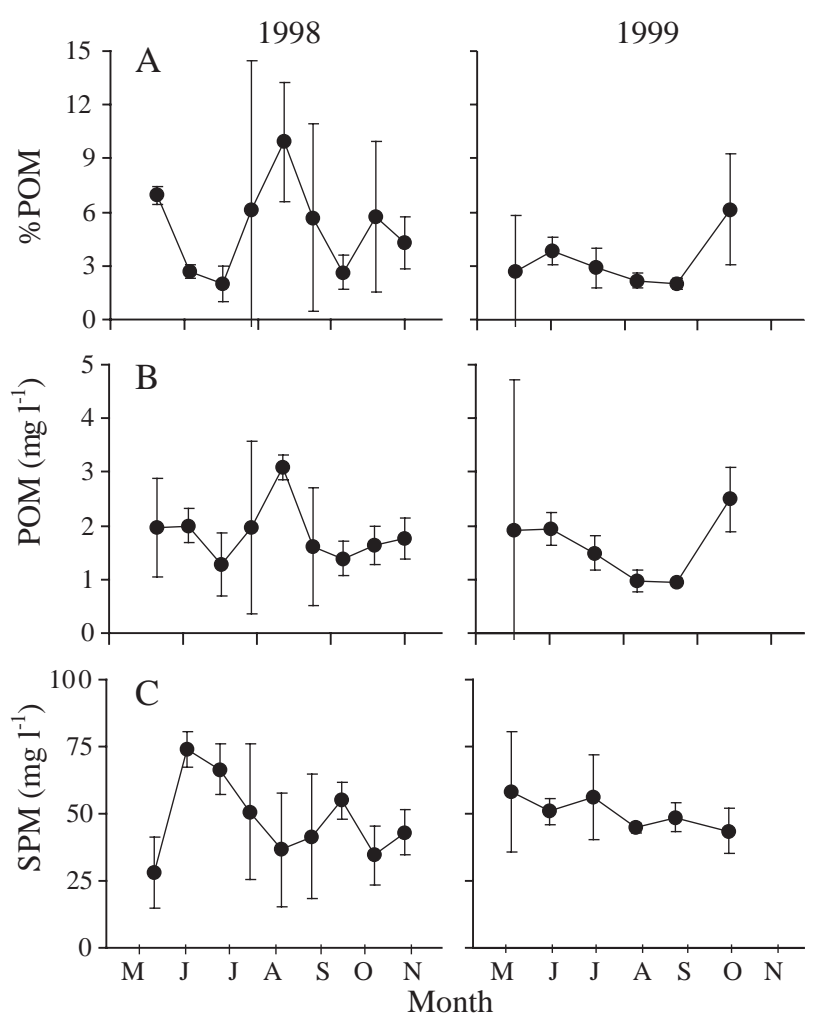

Fig. 7. Average ( $\pm 1 \mathrm{SD}$ ) seston variables in Tracadie Bay, from May to October 1998 and from May to September 1999 (n = 5 sites). SPM: suspended particulate matter; POM: particulate organic matter

ture records were similar at the 5 sampling sites in each of 1998 and 1999 (Fig. 5).

Salinity at sampling sites ranged between 25.8 and 28.3 in 1998 (12 May through 27 October) and between 26.7 and 30.3 in 1999 (31 May through 29 September) (Fig. 6). Salinity was relatively stable during 1998 but decreased over time in 1999. Lower salinity values in spring 1998 compared to 1999 (Fig. 6), were associated with greater rainfall. Consistently higher salinity values were generally recorded at outer embayment Site 1, and lowest values were recorded at inner embayment Site 5.

\section{Seston}

Seston parameters (SPM, POM, \% organic SPM and plant pigments) varied seasonally in Tracadie Bay during 1998 and 1999 (Figs. 7 \& 8). In 1998, maximum average concentrations of SPM occurred in mid-May and early August (9.9 $\mathrm{mg} \mathrm{l}^{-1}$ ) and minimum concentrations in June and September (Fig. 7). Peaks in \% POM values corresponded to minimum concentrations in SPM, with maximum values in June followed by a 

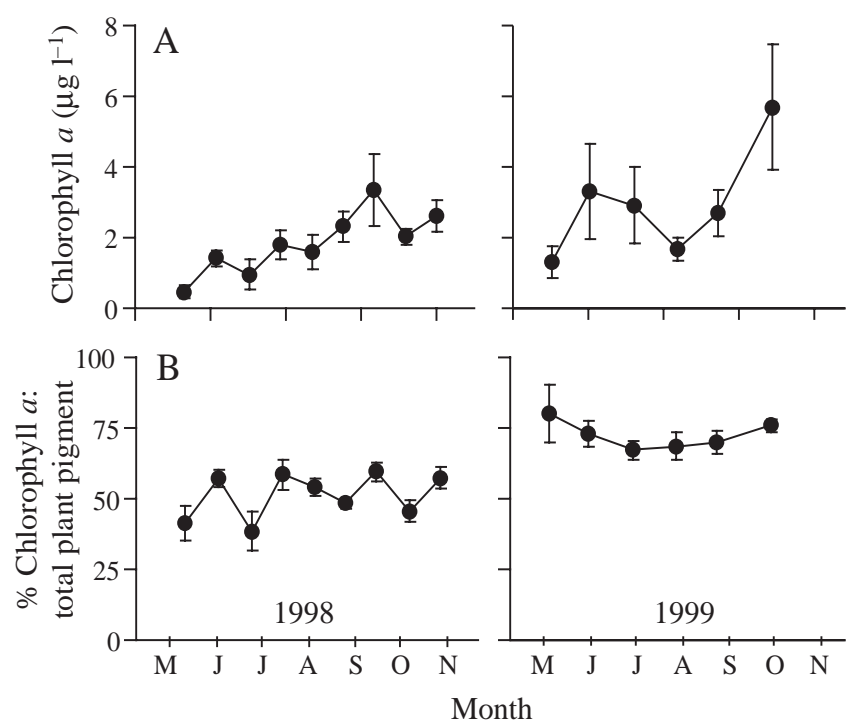

Fig. 8. Average $( \pm 1 \mathrm{SD})$ seston variables in Tracadie Bay from May to October 1998 and from May to September 1999 ( $n=5$ sites). (A) Chlorophyll $a_{i}$ (B) \% chlorophyll a:total plant pigment ratio

smaller peak in mid-September (Fig. 7C). Concentrations of POM remained relatively stable throughout 1998, ranging from 1.0 to $1.9 \mathrm{mg} \mathrm{l}^{-1}$, with the exception of a major peak in early August (Fig. 7B). In 1999, SPM concentrations showed minor variation, with values below $4 \mathrm{mg} \mathrm{l}^{-1}$ during most of the sampling year (Fig. 7C). A small peak was recorded in late May, with a maximum concentration of $6.2 \mathrm{mg} \mathrm{l}^{-1}$ recorded in September. In contrast to SPM concentrations, \% POM values decreased significantly over the sampling season $(\mathrm{r}=0.359, \mathrm{p}=0.039)$ and ranged from 40 to $60 \%$ (Fig. 7A).

Chlorophyll a concentrations increased significantly during each of the 1998 and 1999 sampling seasons (Pearson correlation coefficients, 1998: $r=0.745$, $\mathrm{p}<0.001 ;$ 1999: $\mathrm{r}=0.575, \mathrm{p}<0.001$ ) (Fig. 8). Chlorophyll a concentrations increased from a minimum of $0.5 \mu \mathrm{g} \mathrm{l}^{-1}$ in mid-May to a maximum of $3.3 \mu \mathrm{g} \mathrm{l}^{-1}$ in midSeptember 1998 (Fig. 8). The \% chlorophyll a:total plant pigment ratio in 1998 ranged from 40 to $60 \%$ throughout the sampling year (Fig. 8). Chlorophyll a concentrations in 1999, followed SPM variations, peaked in late May, declined in July and then increased to maximum concentration of $5.7 \mathrm{\mu g} \mathrm{l}^{-1}$ in late September (Fig. 8A). The \% chlorophyll a:total pigment ratio remained relatively stable (67 to $76 \%$ ) during the 1999 sampling season, and was generally higher than values in 1998 (Fig. 8B).

Increased SPM concentrations were not associated with increased chlorophyll a concentrations in 1998 $(\mathrm{r}=0.093, \mathrm{p}>0.05)$ but were in $1999(\mathrm{r}=0.582, \mathrm{p}<0.001)$

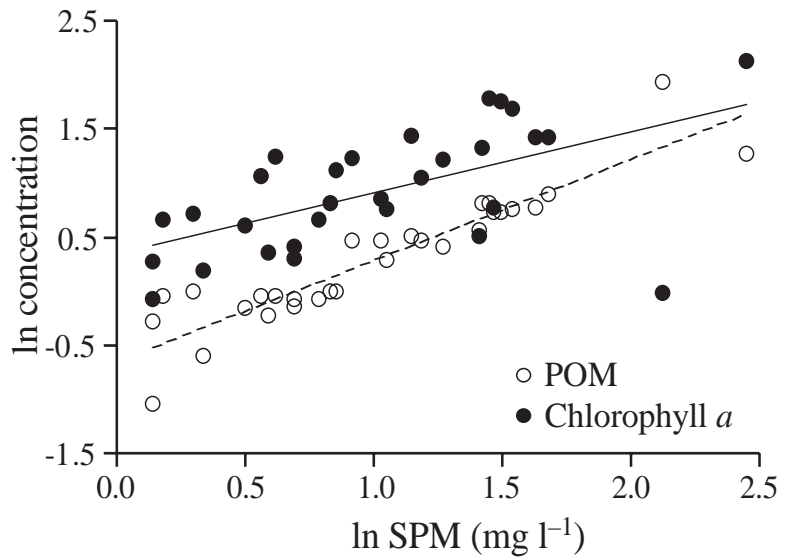

Fig. 9. Pearson correlation analyses between seston parameters in Tracadie Bay from May through September 1999. Represented are $\ln$ POM $\left(\mathrm{mg} \mathrm{l}^{-1}\right)$ and $\ln$ chlorophyll a $\left(\mu \mathrm{g} \mathrm{l}^{-1}\right)$ as a function of $\ln$ SPM $\left(\mathrm{mg} \mathrm{l}^{-1}\right)$

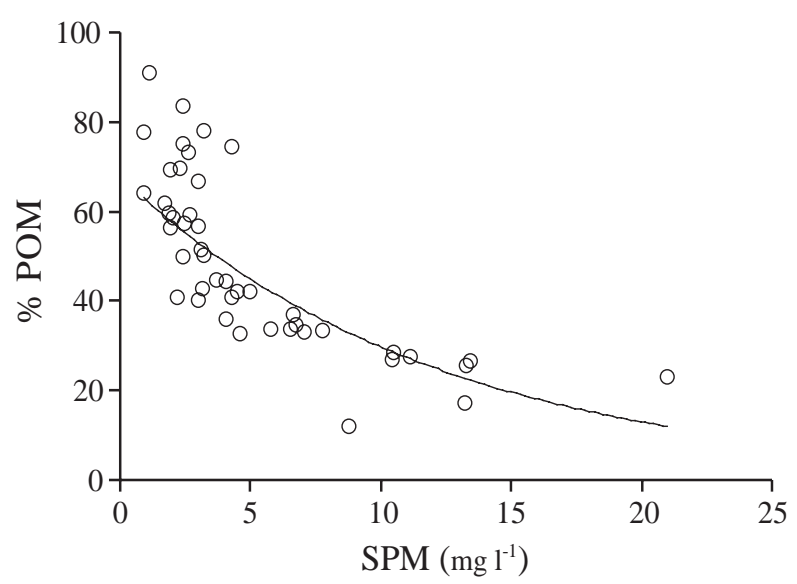

Fig. 10. Relationship between organic content (\% POM) and SPM $\left(\mathrm{mg} \mathrm{l}^{-1}\right.$ ) of seston collected from May to October 1998 in Tracadie Bay. Line fitted by least-squares: \% POM $=0.64$ $( \pm 0.07 \mathrm{SE}) \% \mathrm{SPM}^{-0.09 \pm 0.01}$; where $\mathrm{R}^{2}=0.66$, residual $\mathrm{df}=43$, $\mathrm{p}<0.001$

(Fig. 9). Variations in POM concentrations were marginally associated with SPM concentrations in 1998 ( $\mathrm{r}=$ $0.664, \mathrm{p}<0.001$ ) and highly associated with SPM concentrations in $1999(r=0.922, p<0.001)$ (Fig. 9). However, the organic content of the seston (\% POM) decreased in 1998 from a maximum of $91 \%$ to a minimum of $5 \%$ with increasing SPM concentrations up to $21 \mathrm{mg} \mathrm{l}^{-1}$ (Fig. 10). This relationship was not significant in 1999 ( $p$ > 0.05).

Collectively, the seston results point to an interannual variation in seston dynamics for the bay. In 1998, there were higher peaks in turbidity, with lower organic content and more degraded phytodetritus (lower \% chlorophyll). In 1999, the phytoplankton appeared responsible for more of the suspended parti- 
Table 3. Analyses of variance for seston parameters in Tracadie Bay from May to October 1998 and May to September 1999. SPM: suspended particulate matter; POM: particulate organic matter. ${ }^{*} \mathrm{p}<0.05,{ }^{* *} \mathrm{p}<0.01$

\begin{tabular}{|c|c|c|c|c|}
\hline Variable, Source & df & MS & $F$ & $\mathrm{p}$ \\
\hline \multicolumn{5}{|l|}{ Chlorophyll $a$} \\
\hline Site & 4 & 1.309 & 2.567 & 0.19 \\
\hline Error & 4 & 0.510 & & \\
\hline Year & 1 & 21.420 & $41.995^{* *}$ & 0.003 \\
\hline Error & 4 & 0.510 & & \\
\hline Site (Year) & 4 & 0.510 & 0.279 & 0.89 \\
\hline Error & 65 & 1.830 & & \\
\hline \multicolumn{5}{|l|}{ Phaeophytin a } \\
\hline Site & 4 & 0.599 & 1.901 & 0.27 \\
\hline Error & 4 & 0.315 & & \\
\hline Year & 1 & 5.385 & $17.090^{*}$ & 0.014 \\
\hline Error & 4 & 0.315 & & \\
\hline Site (Year) & 4 & 0.315 & 0.635 & 0.64 \\
\hline Error & 65 & 0.496 & & \\
\hline \multicolumn{5}{|l|}{$\mathrm{SPM}^{\mathrm{a}}$} \\
\hline Site & 4 & 0.502 & 0.604 & 0.68 \\
\hline Error & 4 & 0.831 & & \\
\hline Year & 1 & 2.158 & 2.597 & 0.18 \\
\hline Error & 4 & 0.831 & & \\
\hline Site (Year) & 4 & 0.831 & 1.946 & 0.11 \\
\hline Error & 65 & 0.427 & & \\
\hline \multicolumn{5}{|l|}{$\mathrm{POM}^{\mathrm{a}}$} \\
\hline Site & 4 & 0.368 & 0.573 & 0.70 \\
\hline Error & 4 & 0.643 & & \\
\hline Year & 1 & 0.748 & 1.165 & 0.34 \\
\hline Error & 4 & 0.643 & & \\
\hline Site (Year) & 4 & 0.643 & 2.489 & 0.052 \\
\hline Error & 65 & 0.258 & & \\
\hline aln-transformed & & & & \\
\hline
\end{tabular}

cles and their increased organic content, with a higher percentage of fresh photopigments. Correspondingly, phaeophytin a concentrations were significantly greater in 1998 than in 1999, whereas chlorophyll a concentrations were significantly greater in 1999 than in 1998 (Table 3). Site differences in Table 3 are not significant, indicating that the effect of mussels on their food supply could not be detected by infrequent spot samples at the various locations.

Table 4. Mytilus edulis. Stepwise multiple regressions describing relationship between mussel meat weight as a function of environmental effects in Tracadie Bay in 1998 and 1999. Potential predictor variables included water temperature; ln-transformed concentrations of chlorophyll $a$, organic particulate matter (POM) and suspended particulate matter $(\mathrm{SPM}) ;$ and arcsine-transformed percent organic SPM (\% POM). ${ }^{*} \mathrm{p}<0.05,{ }^{* * *} \mathrm{p}<0.001$

\begin{tabular}{|lcccc|}
\hline Mussel variable & Year & Model & $\mathrm{R}^{2}$ & $\mathrm{p}$ \\
\hline Meat weight & 1998 & $0.292+0.139$ (Chlorophyll a) & $0.54^{* * *}$ & 0.000 \\
Meat weight & 1999 & $0.467-0.011$ (Temperature) & $0.21^{*}$ & 0.022 \\
\hline
\end{tabular}

1998
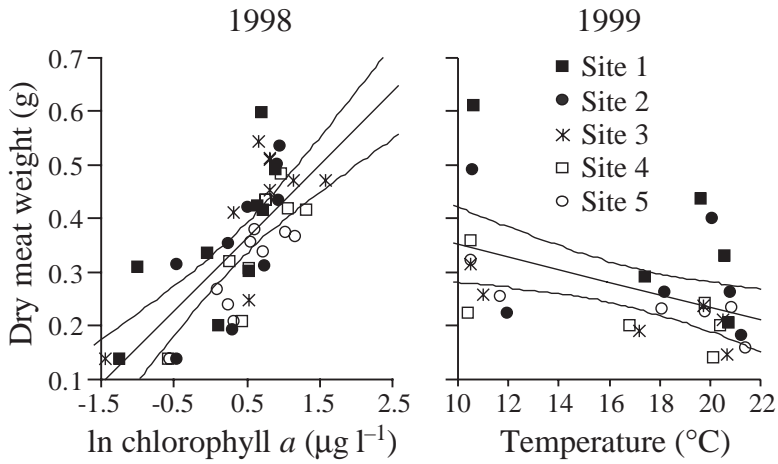

Fig. 11. Mytilus edulis. Regression plots of significant environmental predictor variables for mussel meat weight in Tracadie Bay in 1998 and 1999, showing meat weight (1998) as a function of ln-transformed chlorophyll a concentrations; and meat weight (1999) as a function of temperature. Lines: mean predicted responses $\pm 95 \% \mathrm{CI}$

\section{Mussel growth and environmental associations}

Multiple regression analyses indicated significant relationships between mussel meat weight and changes in chlorophyll $a$ and water temperature (Table 4). The regression model for 1998 indicated that chlorophyll a concentrations explained $54 \%$ of the observed variation in meat weight and the model for 1999 identified water temperature as the most important variable explaining variations in meat weight (Table 4, Fig. 11). The scatter of observed values around the mean predicted response for each regression model generally showed larger values for meat weight at Sites 1 and 2 and lower values at Sites 4 and 5 (Fig. 11). These results suggest that meat growth was more closely tied to food supply in the poorer food year (1998).

\section{DISCUSSION}

Mussel growth has been compared between different estuaries (Mallet \& Carver 1995), but there are few studies that examine spatial variation in growth within estuaries. Most studies have been conducted at a small scale, e.g. growth measured relative to variables such as raft position (Mueller 1996, Fuentes et al. 2000). Similarly, studies of seston depletion have been made at localized small-scales (Newell 1990, Fréchette \& Grant 1991, Navarro et al. 1991, Pilditch et al. 2001), and indicate that the concentration as well as the delivery of food determines the capacity of a location to support growth. At bay-wide scales, Dolmer (1998) measured shell growth in 
Mytilus edulis at various locations in a Danish sound but did not measure environmental factors to correlate with growth. Camacho et al. (1995) conducted $90 \mathrm{~d}$ mussel growth experiments at 3 locations in a Spanish estuary and found that phytoplankton availability controlled live weight increase. The long-term growth response of cultured mussels associated with strong environmental gradients in estuaries and bays has not been addressed despite the potential importance of these gradients to mussel production. This is, however, an effective way to test potential food limitation. In our study, reduced growth was documented in areas distant from tidal renewal over an embayment-wide scale. In addition to spatial variation, there has been little attention paid to interannual variation in growth, especially experiments which begin with new juveniles in the second year. Spatial growth variation was consistent each year despite the differences between the 1998 and 1999 mussels (different initial size and reproductive activity) and the 1998 and 1999 growing conditions (food supply and temperature).

The spatial distribution of mussel growth in Tracadie Bay must be interpreted in terms of hydrodynamic gradients, internal primary production, interannual differences in the culture environment, the effects of temperature on bioenergetics and spawning, and the extent of mussel culture in the bay. Tidal transport is a major source of food replenishment for suspended mussel culture in small, semi-enclosed Atlantic Canadian inlets (Carver \& Mallet 1990, Penney et al. 2001). In Tracadie Bay, a net SE flow along incoming channels results in higher currents and salinities in the outer embayment (Dowd et al. 2001, Grant et al. in press). The best mussel growth occurred in the outermost part of the bay in a high salinity area with fast tidal currents (Site 1 near the entrance to the Gulf of Saint Lawrence). Mussels in this area are exposed to renewed tidally transported food from outside the embayment (Dowd et al. 2001). Diminished tidal currents towards the head of the embayment (Dowd et al. 2001), combined with filtering by the dense culture of mussels, undoubtedly reduced the food supply and reduced mussel growth in the inner embayment.

The data imply that the flux of food, expressed as the product of concentration and current speed, controls the spatial variation in growth with decreasing flux from outer to inner Tracadie Bay. We have not documented the gradient of fluxes in the present study, but previous modelling and field work in Tracadie Bay unequivocally established that there is reduced flushing in the interior of the bay as well as reduced particle exchange with the coastal ocean (Dowd 2005, Grant et al. in press). This is consistent with previous ideas relating seston depletion to the balance of tidal food renewal and removal due to suspension feeding (Dame
\& Prins 1998), as well as previous field studies of raftcultured mussels in Spain (Camacho et al. 1995), and bottom-cultured clams in the USA (Grizzle \& Lutz 1989). Dowd (2003) modelled seston dynamics in Tracadie Bay and predicted that seston flux differed by an order of magnitude between inner and outer parts of the bay. Our study examines food delivery from the animal context, expressing food limitation through reduced growth along a flux gradient.

Seston concentration may be examined as a forcing variable instead of flux, but a consistent inner-outer gradient in this variable corresponding to gradients in growth is not always preserved due to tidal and hydrodynamic variations affecting seston concentration and distribution. In addition, the Winter Bay region is a source of upland nutrients that may have a local influence on primary production and seston concentration. Temporal variations in seston characteristics may vary such that discrete seston samples would not be expected to characterize even average conditions. There was no indication of persistent spatial differences in seston concentration among sites. The significance of the multiple regression analyses demonstrated the strength of the mussel growth-food interaction, which was detected using only single water samples. Dowd's (2003) seston model of Tracadie Bay indicates that seston levels in the bay are controlled by flushing in the mouth of the bay, and by mussel grazing and internal primary production at the head of the bay. In this case, the water samples reflect an interaction between incoming depleted seston and internally produced and resuspended seston. Samples taken over shorter time scales suggest the importance of both resuspension and estuarine flushing to seston concentrations (Grant et al. in press). The influence of mussels has also been suggested in calculations by Meeuwig (1999) that indicated a strong negative relationship between mussel and phytoplankton biomass in PEI embayments with mussel culture.

There appeared to be a fundamental temporal change in seston quality and quantity between years beyond spatial differences in seston flux. The negative relationship between SPM and \% POM in 1998 suggests that resuspended particles were important in some of the seston samples (Hawkins et al. 1996, 1998). Wind-induced resuspension serves to decrease the quality of the food available to mussels while increasing the total quantity available (Berg \& Newell 1986, Cranford et al. 1998). In 1999, there was a positive relationship between SPM and both POM and chlorophyll, indicating that higher particle loads were associated with phytoplankton. Based on these observations, 1999 may be predicted to have been a superior growth year to 1998. The net growth (meat weight at the end of the sampling period) was in fact significantly greater in 
1998 than in 1999. This implies that it is not the annual characterization of seston that is important but the temporal characterization. In 1998, chlorophyll showed a fairly linear increase during the year that was reflected in the linear pattern of meat weight for that year. These similar trends account for the significant regression between chlorophyll and meat weight for 1998. Site 3 at the mouth of Winter Bay showed accelerated growth for 1998 even compared to the outer sites. Rainfall in May and June 1998 was 3 to 6 times more than in 1999 (Environment Canada climate summaries), potentially resulting in nutrient enrichment from agricultural runoff and subsequent phytoplankton blooms in Winter Bay. Agricultural activities on PEI exert a large influence on nutrient levels within surrounding embayments (Meeuwig 1999). In 1999, meat growth had a slow start, but poor food supplies early in the year are not obvious from the seston record. There was increased growth late in the year corresponding to a surge in chlorophyll $a$, with much of the weight gain due to gonad development in preparation for spawning. An autumn phytoplankton bloom, typical of the area (Brylinski \& Sephton 1991), occurred in September 1999, resulting in the highest chlorophyll a concentrations $\left(\sim 6 \mu \mathrm{g} \mathrm{l}^{-1}\right)$ observed in the study. These differences indicate that the food environment is variable, and that a 'typical' year may be elusive when constructing boundary conditions for use in models of culture carrying-capacity.

Growth trajectories analyzed with polynomial regressions provided useful insights into the spatial variation in growth. Curves have been applied to describe and compare bivalve growth rates in many studies (see review Seed \& Suchanek 1992). The von Bertalanffy growth equation is a common example of using regression for this purpose, but it does not have the flexibility in shape that we were able to obtain using polynomials. For example, the spatial variation in growth was similar in both sampling years but the growth trajectories, particularly for meat weight, differed between years. In 1998, meat weight became increasingly asymptotic from the outer to inner sites. The outer site trends were linear without the indication of food limitation implied by the asymptote of Sites 3, 4 and 5. In 1999, mussels at the outer sites appeared to grow exponentially following their early-year inactivity. However, this gain was increasingly attenuated going from outer to inner sites, to the extent that there was little or no net increase in meat weight at Sites 3,4 and 5.

Annual and spatial differences in mussel growth were much more pronounced when measured as meat weight than as shell length. Meat weight exhibited substantial decreases and increases in response to endogenous and exogenous factors during 1999, while shell length growth rates remained stable. These data confirm the suggestion by Grant (1999) that meat weight is a much more sensitive growth parameter to environmental change than shell length. Shell growth in mussels can even continue at sub-maintenance food levels despite a loss in meat weight (see review by Hawkins \& Bayne 1992). We examined condition index as a growth variable that incorporated shell and tissue growth, but this variable offered no further insight than tissue weight alone.

The emphasis of our study was on the effects of food on mussel growth, but temperature is important in determining upper limits to growth as well as spawning. Temperature was the only significant variable in the 1999 multiple regression for tissue weight, although it explained only $21 \%$ of the growth variance. Sustained periods of water temperatures above $20^{\circ} \mathrm{C}$ from lateJune to mid-summer 1999 probably had a negative effect on growth. Depending on food availability, mussels acclimate and establish a stable scope for growth over a wide temperature range below $20^{\circ} \mathrm{C}$, but metabolic compensation (respiration and clearance rates) above $20^{\circ} \mathrm{C}$ declines rapidly (Bayne et al. 1976 [review], Widdows 1978). Decreased growth and/or mortality in midsummer are a result of warm water temperatures together with limited food availability on the Atlantic coast of Canada (Myrand et al. 1998). Substantial increases in meat weight occurred from mid-summer into autumn at all sites during 1999, indicating improved growing conditions throughout the embayment. An increase in water temperature will initiate gamete production if sufficient food is available (Bayne \& Worrall 1980). This was apparently the case in autumn 1999.

The pattern of spatial variability in mussel growth, representing decreased growth rates in the inner bay relative to the outer bay, provides evidence that the density of cultured mussels in Tracadie Bay was exceeding the available food supply. This study demonstrated that the use of sentinel mussels, concurrent with basic environmental monitoring, provides a practical approach to assess bay-wide shellfish management practices.

Acknowledgements. We thank the aquaculturists of Tracadie Bay for cooperation and assistance with field work, particularly J. MacLeod. B. Gillis and personnel of the PEI Department of Fisheries provided field support. S. Komadina-Douthwright, F. MacGuire, N. LeBlanc and M. Ouellette assisted with sample processing. Funding for this work was provided by the Federal Government Workforce Adjustment Policy (L.W.) and through the Department of Fisheries and Oceans.

\section{LITERATURE CITED}

Bacher C, Grant J, Hawkins AJS, Fang J, Zhu M, Besnard M (2003) Modelling the effect of food depletion in Sungo Bay (China). Aquat Living Resour 16:10-24

Bayne BL, Worrall CM (1980) Growth and production of mus- 
sels, Mytilus edulis from two populations. Mar Ecol Prog Ser 3:317-328

Bayne BL, Widdows J, Thompson RJ (1976) Physiological integrations. In: Bayne BL (ed) Marine mussels: their ecology and physiology. IBP No. 10. Cambridge University Press, Cambridge, p 261-291

Berg JA, Newell RIE (1986) Temporal and spatial variations in the composition of seston available to the suspension feeder Crassostrea virginica. Estuar Coast Shelf Sci 23:375-386

Brown JR (1988) Multivariate analyses of the role of environmental factors in seasonal and site-related growth variation in the Pacific oyster Crassostrea gigas. Mar Ecol Prog Ser 45:225-36

Brylinsky M, Sephton TW (1991) Development of a computer simulation model of a cultured blue mussel (Mytilus edulis) population. Can Tech Rep Fish Aquat Sci 1805:1-81

Camacho AP, Labarta U, Beiras R (1995) Growth of mussels (Mytilus edulis galloprovincialis) on cultivation rafts: influence of seed source, cultivation site and phytoplankton availability. Aquaculture 138:349-362

Carver CEA, Mallet AL (1990) Estimating the carrying capacity of a coastal inlet for mussel culture. Aquaculture 88:39-53

Côté J, Himmelman JH, Claereboudt HR (1994) Separating the effects of limited food and space on growth of the giant scallop Placopecten magellanicus in suspended culture. Mar Ecol Prog Ser 106:85-91

Cranford PJ, Emerson CW, Hargrave BT, Milligan TG (1998) In situ feeding and absorption responses of sea scallops Placopecten magellanicus (Gmelin) to storm-induced changes in the quantity and composition of the seston. J Exp Mar Biol Ecol 219:45-70

Dame RF, Prins TC (1998) Bivalve carrying capacity in coastal ecosystems. Aquat Ecol 31:409-421

Dolmer P (1998) Seasonal and spatial variability in growth of Mytilus edulis L. in a brackish sound: comparisons of individual mussel growth and growth of size classes. Fish Res $34: 17-26$

Dolmer P (2000) Feeding activity of mussels Mytilus edulis related to near-bed currents and phytoplankton biomass. J Sea Res 44:221-231

Dowd M (2000) Oceanography and shell fish production: a biophysical synthesis using a simple model. Bull Aqua Assoc Can 100-2:3-9

Dowd M (2003) Seston dynamics in a tidal inlet with shellfish aquaculture: a model using tracer equations. Estuar Coast Shelf Sci 57:523-537

Dowd M (2005) A bio-physical coastal ecosystem model for assessing environmental effects of marine bivalve aquaculture. Ecol Model 183:323-346

Dowd M, Page FH, Losier R, McCurdy P, Bugden G (2001) Physical oceanography of Tracadie Bay, PEI: analysis of sea level, current, wind and drifter data. Can Tech Rep Fish Aquat Sci 2347:1-77

Fréchette M, Grant J (1991) An in situ estimation of the effect of wind-driven resuspension on the growth of the mussel Mytilus edulis L. J Exp Mar Biol Ecol 148:201-213

Fuentes J, Gregorio V, Giraldez R, Molares J (2000) Within-raft variability of the growth rate of mussels, Mytilus galloprovincialis, cultivated in the Ria de Arousa (NW Spain). Aquaculture 189:39-52

Grant J (1996) The relationship of bioenergetics and the environment to the field growth of cultured bivalves. J Exp Mar Biol Ecol 200:239-256

Grant J (1999) Preliminary models of seston depletion and growth variation in cultured mussels. Bull Aqua Assoc Can 99-2:5-8

Grant J, Cranford P, Hargrave B, Carreau M, Schofield B, Armsworthy S, Burdett-Coutts V, Ibarra D (in press) A model of aquaculture biodeposition for multiple estuaries and field validation at mussel (Mytilus edulis) culture sites in Eastern Canada. Can J Fish Aquat Sci

Grizzle R, Lutz RA (1989) A statistical model relating horizontal seston fluxes and bottom sediment characteristics to growth of Mercenaria mercenaria. Mar Biol 102:95-105

Hawkins AJS, Bayne BL (1992) Physiological processes, and the regulation of production. In: Gosling E (ed) The mussel Mytilus: ecology, physiology, genetics and culture. Elsevier Science, Amsterdam, p 171-222

Hawkins AJS, Smith RFM, Bayne BL, Heral M (1996) Novel observations underlying the fast growth of suspensionfeeding shellfish in turbid environments: Mytilus edulis. Mar Ecol Prog Ser 131:179-190

Hawkins AJS, Smith RFM, Tan SH, Yasin ZB (1998) Suspension-feeding behaviour in tropical bivalve molluscs: Perna viridis, Crassostrea belcheri, Crassostrea iradelei, Saccostrea cucculata and Pinctada margarifera. Mar Ecol Prog Ser 166:173-185

Mallet AL, Carver CE (1995) Comparative growth and survival patterns of Mytilus trossulus and Mytilus edulis in Atlantic Canada. Can J Fish Aquat Sci 52:1873-1880

Meeuwig JJ (1999) Predicting coastal eutrophication from land-use: an empirical approach to small non-stratified estuaries. Mar Ecol Prog Ser 176:231-241

Motulsky H, Christopoulos A (2003) Fitting models to biological data using linear and nonlinear regression: a practical guide to curve fitting. Oxford University Press, Oxford

Mueller KW (1996) A preliminary study of the spatial variation in growth of raft-cultured blue mussels Mytilus trossulus in northern Puget Sound, Washington. J World Aquacult Soc 27:240-246

Myrand B, Tremblay R, Sevigny JM, Gunderley H, Himmelman JH (1998) What did we learn about summer mortality of suspension-cultured mussels in the Magdalen Islands, Quebec? Bull Aqua Assoc Can 99-2:9-13

Navarro E, Iglesias JIP, Camacho AP, Labarta U, Beiras R (1991) The physiological energetics of mussels (Mytilus galloprovincialis Lmk.) from different cultivation rafts in the Ria de Arosa (Galicia, NW Spain). Aquaculture 94:197-212

Neter J, Kutner MH, Nachtsheim CJ, Wasserman W (1996) Applied linear regression models, 3rd edn. McGraw-Hill, New York

Newell CR (1990) The effects of mussel (Mytilus edulis Linnaeus, 1758) position in seeded bottom patches on growth at subtidal lease sites in Maine. J Shellfish Res 9:113-118

Parsons GJ, Dadswell MJ (1992) Effect of stocking density on growth, production and survival of the giant scallop, Placopecten magellanicus, held in intermediate and suspended culture in Passamaquoddy Bay, New Brunswick. Aquaculture 103:291-309

Penney WR, McKenzie CH, Mills TJ (2001) Assessment of the particulate food supply available for mussel (Mytilus spp.) farming in a semi-enclosed northern inlet. Estuar Coast Shelf Sci 53:107-121

Pilditch CA, Grant J, Bryan KR (2001) Seston supply to sea scallops (Placopecten magellanicus) in suspended culture. Can J Fish Aquat Sci 58:241-253

Scarratt DJ (2000) Development of the mussel industry in eastern Canada. Bull Aqua Assoc Can 100-2:37-40

Seed R, Suchanek TH (1992) Population and community ecology of Mytilus. In: Gosling EM (ed) The mussel Mytilus: ecology physiology genetics and culture. Elsevier, Amsterdam, p 87-169

Snedecor GW, Cochran WG (1989) Statistical methods, 8th edn. Iowa State University Press, Ames, IA

Widdows J (1978) Physiological indices of stress in Mytilus edulis. J Mar Biol Assoc UK 58:125-14 